\title{
Peatland Microbial Communities as Indicators of the Extreme Atmospheric Dust Deposition
}

\author{
B. Fiałkiewicz-Koziel • B. Smieja-Król • \\ T. M. Ostrovnaya $\cdot$ M. Frontasyeva $\cdot$ A. Siemińska • \\ M. Lamentowicz
}

Received: 2 September 2014 / Accepted: 2 February 2015 /Published online: 18 March 2015

(C) The Author(s) 2015. This article is published with open access at Springerlink.com

\begin{abstract}
We investigated a peat profile from the Izery Mountains, located within the so-called Black Triangle, the border area of Poland, Czech Republic, and Germany. This peatland suffered from an extreme atmospheric pollution during the last 50 years, which created an exceptional natural experiment to examine the impact of pollution on peatland microbes. Testate amoebae (TA), Centropyxis aerophila and Phryganella
\end{abstract}

Electronic supplementary material The online version of this article (doi:10.1007/s11270-015-2338-1) contains supplementary material, which is available to authorized users.

B. Fiałkiewicz-Kozieł $(\bowtie) \cdot$ A. Siemińska $\cdot$ M. Lamentowicz Department of Biogeography and Palaeoecology,

Faculty of Geographical and Geological Sciences,

Adam Mickiewicz University,

Dzięgielowa 27, 61-680 Poznań, Poland

e-mail: basiaf1234@poczta.fm

\section{B. Smieja-Król}

Faculty of Earth Sciences, University of Silesia,

Będzińska 60, 41-200 Sosnowiec, Poland

T. M. Ostrovnaya $\cdot$ M. Frontasyeva

Department of Neutron Activation Analysis,

Frank Laboratory of Neutron Physics Joint Institute for

Nuclear Research, Dubna, Russian Federation

M. Lamentowicz

Laboratory of Wetland Ecology and Management \&

Department of Biogeography and Palaeoecology,

Adam Mickiewicz University in Poznań, Poznań, Poland

M. Lamentowicz

Department of Meteorology, Poznan University of Life

Sciences, Piątkowska 94, 60-649 Poznań, Poland acropodia, were distinguished as a proxy of atmospheric pollution caused by extensive brown coal combustion. We recorded a decline of mixotrophic TA and development of agglutinated taxa as a response for the extreme concentration of $\mathrm{Al}\left(30 \mathrm{~g} \mathrm{~kg}^{-1}\right)$ and $\mathrm{Cu}$ $\left(96 \mathrm{mg} \mathrm{kg}^{-1}\right)$ as well as the extreme amount of fly ash particles determined by scanning electron microscopy (SEM) analysis, which were used by TA for shell construction. Titanium (5.9\%), aluminum (4.7\%), and chromium $(4.2 \%)$ significantly explained the highest percentage of the variance in TA data. Elements such as $\mathrm{Al}, \mathrm{Ti}, \mathrm{Cr}, \mathrm{Ni}$, and $\mathrm{Cu}$ were highly correlated $(r>0.7$, $p<0.01$ ) with pseudostome position/body size ratio and pseudostome position. Changes in the community structure, functional diversity, and mechanisms of shell construction were recognized as the indicators of dust pollution. We strengthen the importance of the TA as the bioindicators of the recent atmospheric pollution.

Keywords Testate amoebae $\cdot$ Pollution $\cdot$ Fly ash particles · Proxy

\section{Introduction}

Ombrotrophic peatlands are an important archive of atmospheric pollution (Shotyk 1996). They give essential information about past and present changes of the environment, especially, when applying a multiproxy approach (Lamentowicz et al. 2013). Testate amoebae, unicellular protists, are one of the most abundant 
microbial group of the peatland ecosystem and represent soil food web structure as they are microbial top predators (Jassey et al. 2013a). These sensitive bioindicators are often used to reconstruct past hydrology and trophy (Swindles et al. 2014) as well as atmospheric pollution (Payne et al. 2012), because their shells are preserved in the peat after death. Recently, analysis of the TA functional traits revealed intriguing relationships between hydrology and pseudostome position (Lamentowicz et al. 2015); however, it has not been studied deeply how the atmospheric pollution affects the functional diversity of microbes. Furthermore, nothing is known about the response of these microbes to fly ash deposition resulting from coal combustion.

We investigated a peat profile from Jagnięcy Potok in the Izery Mountains, located within the so-called Black Triangle (Jędrysek et al. 2002; Szynkiewicz et al. 2008), the border area of Poland, Czech Republic, and Germany. This peatland suffered from an extreme atmospheric pollution during the last 50 years, which created an exceptional natural experiment to examine the impact of pollution on peatland microbes. We hypothesized that TA responded significantly to the dust deposition on the level of functional diversity, community structure, morphology, and physiology.

The objectives of our research are to (i) assess the level of pollution using geochemistry, (ii) determine the chemical composition of dust particles building the shell of TA using a SEM, and (iii) infer the response of testate amoebae communities and their functional traits to the toxic dust pollution.

\section{Methods}

Seventeen dry samples of $1 \mathrm{~g}$ were used for epithermal neutron activation analysis (ENAA) to determine the concentrations of $\mathrm{Al}, \mathrm{As}, \mathrm{Cr}, \mathrm{Cu}, \mathrm{Fe}, \mathrm{Ni}, \mathrm{Sr}$, and $\mathrm{Ti}$. ENAA, which is effective in the simultaneous assessment of the content of important air pollutants (Frontasyeva and Steinnes 2005), was carried out in the IBR-2 pulsed fast reactor in Dubna (Russia). Samples of TA were prepared according to methods described by Booth et al. (2010). These samples were washed over sieves of $300 \mu \mathrm{m}$ mesh size; the fraction below $300 \mu \mathrm{m}$ was used for the analysis. The TA was counted at magnifications of $\times 200$ and $\times 400$ and identified using available literature (Grospietsch 1958; Mazei and Tsyganov 2006; Ogden and Hedley 1980).
To determine the mineral composition of every peat sample and TA shells, SEM equipped with an energy dispersive system (Philips XL30 ESEM/EDS), allowing chemical analyses of individual peat components, was used (Smieja-Król and Fiałkiewicz-Kozieł 2014).

Hellinger-transformed testate amoebae community matrix was used as a response matrix (Legendre and Gallagher 2001). The redundancy analyses (RDA) to relate abiotic variables to biotic communities were employed. The significance of the model, axes, and variables was tested using a Monte Carlo test with 999 permutations. Computations were performed in R 3.0.1 (Team 2013) using the vegan package (Oksanen et al. 2011).

Three morphological traits were selected to infer the past pollution: metabolic status of the species, body size, and position of the shell aperture. The metabolic status of TA (presence/absence of endosymbiotic algae) indicates whether a specimen is mixotrophic (i.e., organisms able to combine autotrophic and heterotrophic nutrition) or heterotrophic. Metabolic status of TA was showed to cope with environmental settings such as moisture, temperature, and light (Jassey et al. 2011; Wilken et al. 2013). Those traits are expected to reflect community structure and disturbance connected with the pollution (Tsyganov et al. 2012; Lamentowicz et al. 2013). The position of the shell aperture (semicontinuous and variably coded as $0=$ axial, $1=$ terminal, $2=$ sub-terminal aperture) revealed a gradient from exposed to protected aperture. We analysed the response of individual morphological traits in the peat-core by calculating the community-weighted mean (CWM) of each standardized trait (Lamentowicz et al. 2015).

\section{Results and Discussion}

The strongest change in all determined variables was noticed at 10-12 cm peat layer (Fig. 1). A significant increase in the concentration of $\mathrm{Al} ; 30 \mathrm{~g} \mathrm{~kg}^{-1}$ (by a factor of 10) and Ti; $2400 \mathrm{mg} \mathrm{kg}^{-1}$, followed by As; $20 \mathrm{mg} \mathrm{kg}^{-1}, \mathrm{Cr} ; 85 \mathrm{mg} \mathrm{kg}^{-1}, \mathrm{Cu} ; 96 \mathrm{mg} \mathrm{kg}^{-1}$ (factor of 5), $\mathrm{Fe} ; 1 \%, \mathrm{Ni} ; 18 \mathrm{mg} \mathrm{kg}^{-1}$, and $\mathrm{Sr} ; 29 \mathrm{mg} \mathrm{kg}^{-1}$ was observed in comparison with values obtained in the lower part of the peat $(29-30 \mathrm{~cm})$. The concentrations were also distinctly higher than those in another Polish peatlands (Holynska et al. 1998; De Vleeschouwer et al. 2009). Anthropogenic particles, originating from brown 


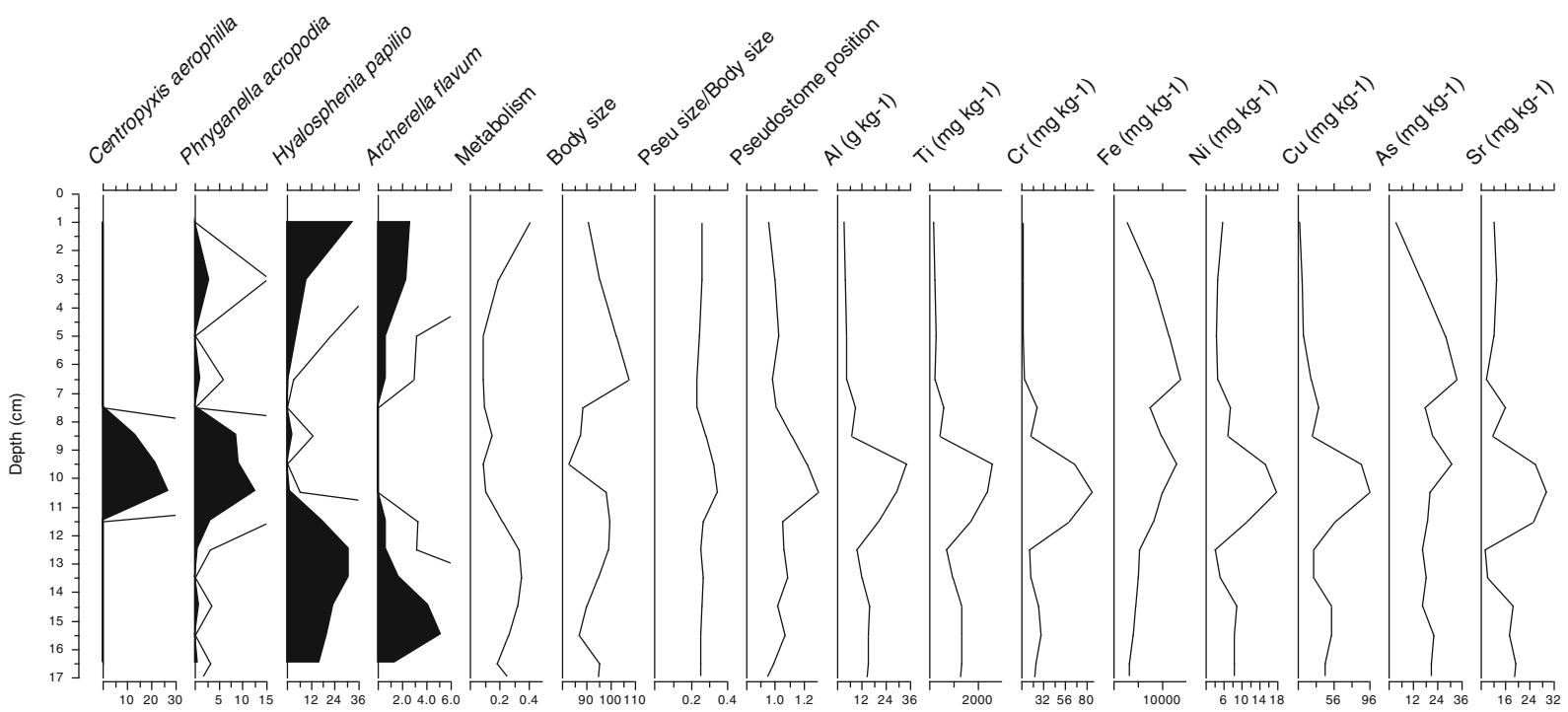

Fig. 1 The most abundant testate amoebae, functional traits and elements concentration in the Izery along the peat profile

coal combustion, dominate in the layer, constituting $66 \%$ of all inorganic particles analyzed. These particles comprised irregular, spongy aluminosilicates $\left(\mathrm{Al}_{2} \mathrm{O}_{3}>\right.$ $\mathrm{SiO}_{2}$ ) up to $50 \mu \mathrm{m}$ large and glassy, often hollow spheroidal aluminosilicates $\left(\mathrm{SiO}_{2}>\mathrm{Al}_{2} \mathrm{O}_{3}\right)$ with diameters ranging between 0.8 and $10 \mu \mathrm{m}$ (average $2.6 \mu \mathrm{m}$ ). The occurrence of both the spongy and glassy aluminosilicates and extreme concentration of titanium clearly indicate the impact of humans on investigated peatland (Smieja- Król et al. 2010; Smieja-Król and FiałkiewiczKozieł 2014).

Mixotrophic (living in symbiosis with the green algae) (Gomaa et al. 2014) TA (Archerella flavum and Hyalosphenia papilio) species decreased, and then agglutinating (including extraneous mineral particles in shell) species-Centropyxis aerophila and Phryganella acropodia-became more abundant (Fig. 1). $P$. acropodia is usually regarded as an indicator of the low water table in Sphagnum peatland (Lamentowicz and Mitchell 2005) and C. aerophila is found in the mineral soil (Deflandre 1929). Considering functional traits of TA, we observed a shift from acrostomic to plagiostomic type of aperture that might suggest a transformation of the food web into the lower trophic level (Jassey et al. 2013b). Analysing the community-weighted means of specific functional traits, we found that pseudostome position is the most significant functional trait that determine the surviving of TA in the extreme pollution as well as increased input of the dust (Fig. 1). Also, the metabolism curve shows a decline of mixotrophic species that most possibly is connected with the light limitation. Furthermore, body size trait curve shows a decrease of large TA species during the pollution event. The considerable change within the functional diversity expresses the transformation of the food web triggered by the atmospheric pollution that shortened the food chain (Jassey et al. 2013a). This type of signal could have been interpreted as the dry shift (presence of dry TA indicators) according to community structure; however, possessing geochemical data we can be sure that it was generated by the air pollution.

Our analysis revealed a correlation between TA functional traits and measured elements (Supplementary Table 1). The highest number of high $(r>0.7, p<0.01)$ Pearson correlation was obtained for pseudostome position/body size ratio and $\mathrm{Al}, \mathrm{Ti}, \mathrm{Cr}, \mathrm{Ni}$, and $\mathrm{Cu}$. The second trait was pseudostome position that correlates highly with $\mathrm{Al}, \mathrm{Cr}$, and Ni. Metabolism revealed high but inverse correlation with Fe. Actually, such strong relationships support our inferences of the strong past impact of the atmospheric pollution on the soil microbes.

Redundancy analysis (RDA) revealed a significant $(p<0.001)$ response of TA to the extreme pollution event. Furthermore, it indicates the influence of ash content$\mathrm{Al}, \mathrm{Cu}, \mathrm{Cr}$, and $\mathrm{Ti}$ - at significant level (Fig. 2). Permutation test showed that titanium (5.9\%), aluminum (4.7\%), and chromium (4.2\%) are statistically significant and explain the highest percentage of the variance in TA data (Supplementary Table 2). 


\section{RDA Izery Bog}

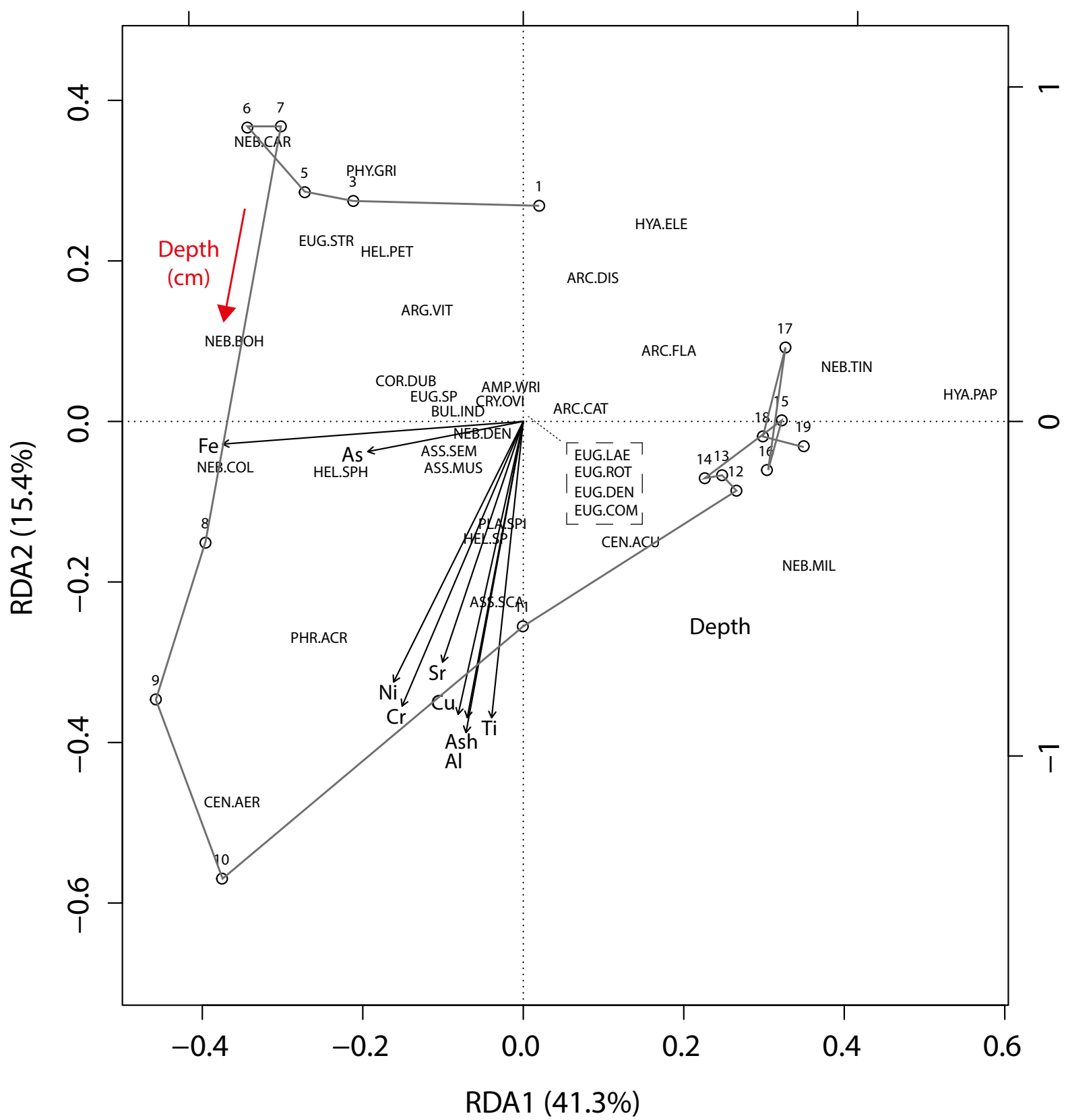

Fig. 2 Redundancy analysis (RDA) of the pollution event in the Izery Mountains. Full model explains $75 \%$ of the variation in species matrix. First axis explains $41.3 \%$ and second $15.4 \%$ of variance, both axes are significant $(p<0.001)$. The most significant variables in the model are $\operatorname{Ti}(p<0.01)$ as well as $\mathrm{Al}$ and $\mathrm{Cr}(p<0.01)$ (Supplementary Table 2). The grey line connects particular samples along the profile depth. Species names abbreviations: AMP FLA Archerella flavum, ARC CAT Arcella catinus, ARC DIS Arcella discoides, ARC FLA Archerella flavum, ARG VIT Argynnia vitraea, ASS MUS Assulina muscorum, ASS SCA Assulina scandinavica, ASS SEM Assulina seminulum, BUL IND Bullinularia indica, COR DUB Corythion dubium, CEN AER Centropyxis aerophila, CEN ACU Centropyxis aculeata, CRY OVI Cryptodifflugia oviformis, EUG COM Euglypha compressa, EUG DEN Euglypha denticulata, EUG ROT Euglypha rotunda, EUG LAE Euglypha laevis, EUG STR Euglypha strigosa, EUG SP Euglypha sp., HEL PET Heleopera petricola, HEL SP Heleopera sp., HEL SPH Heleopera sphagni, HYA ELE Hyalosphenia elegans, HYA PAP Hyalosphenia papilio, NEB MIL Nebela militaris, NEB TIN Nebela tincta, NEB COL Nebela collaris, NEB DEN Nebela dentistoma, NEB CAR Nebela carinata, NEB BOH Nebela bohemica, PHR ACR Phryganella acropodia, PHY GRI Physochila griseola, PLA SPI Placocista spinosa 
Copper and aluminum are potentially the most toxic elements; however, the form of their deposition is the most important factor that could strongly affect the microbial biodiversity. It is known that $\mathrm{Al}$ is especially mobile and toxic in acid pH (Kabata-Pendias and Pendias 1999). Although we were unable to achieve the chemical speciation of copper and aluminum, the large internal surface area of the spongy aluminosilicates
Fig. 3 Scanning electron microscope images and EDS spectra of TA shells: a shell of Difflugia $s p$. covered by fly ashes; b and $\mathbf{c}$ EDS spectra of anthropogenic aluminosilicates from (a); d Phryganella $s p$.- anthropogenic particles that are built into the test. Anthropogenic particles are indicated by crosses, the identified natural particles are $Q$ quartz, $F$ feld-potassium feldspar, $M$ muscovite, $D$ diatom fragments. For more details about the SEM analysis of mineral composition of peat samples as well as testate amoeba shell please see Smieja-Król and Fiałkiewicz-Kozieł (2014)
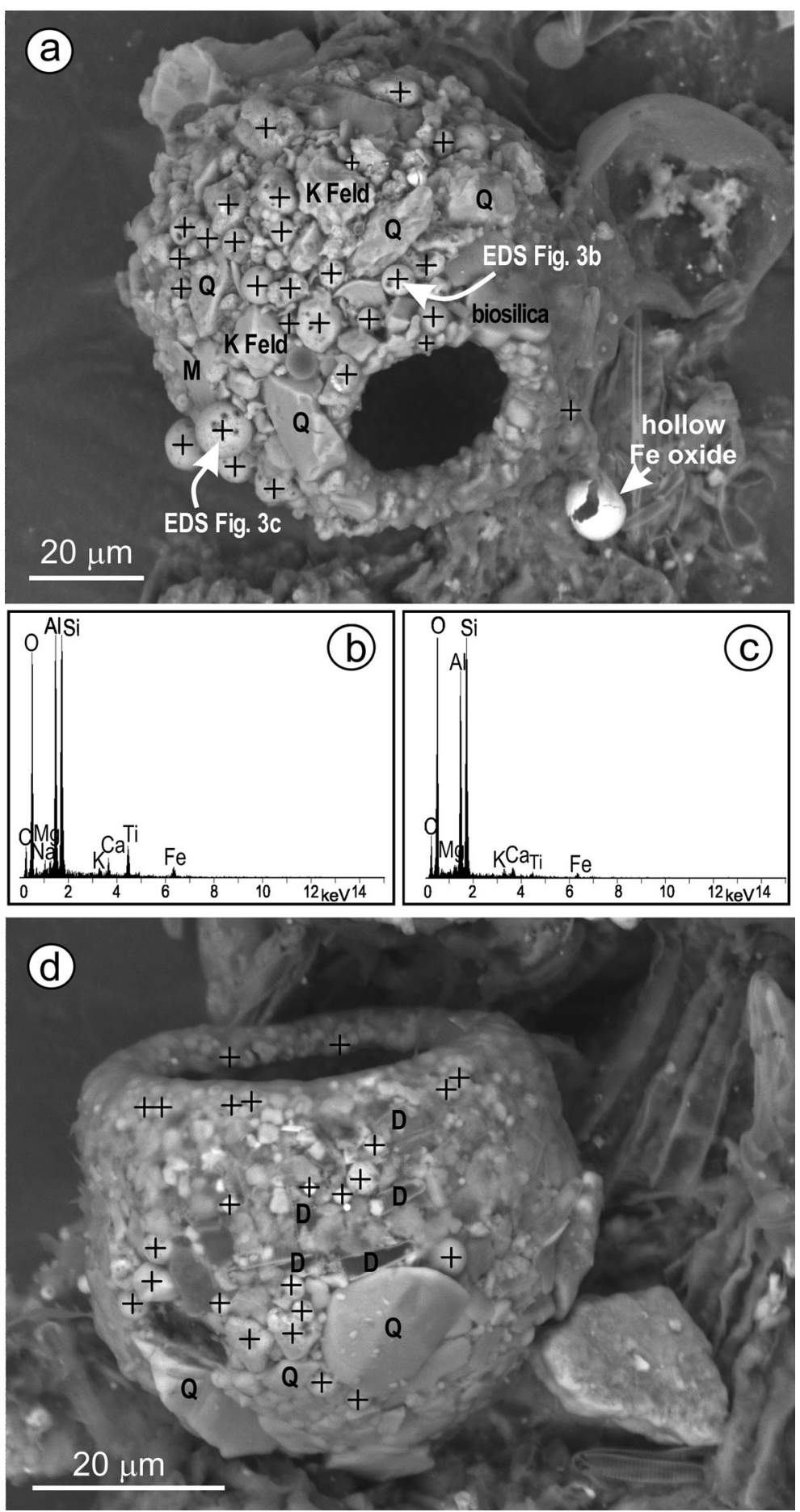
and Sphagnum parts with absorbed aluminum indicate a possible release of this element to peatland briosphere and possible harmful effects.

Centropyxis and Phryganella used small spheroidal aluminosilicates for shell construction (Fig. 3). Silicabiomineralizing testate amoebae need $\mathrm{Si}$ in diluted form for shell construction (e.g., Euglypha sp.). As a consequence, they use potentially deleterious water, a fact which seems to be insignificant for life conditions of Centropyxis or Phryganella, but might be harmful for the construction of idiosomic and organic shells. Other paleo studies in Poland showed the development of C. aerophila during deforestation being a result of soil openness and erosion (Lamentowicz et al. 2009; Lamentowicz et al. 2007). However, in those studies the dust did not have toxic character.

The other possible explanation for limitation of some TA is the influence of ash on mixotrophic species by blocking the access to light as well as the supply of mineral particles (lacking in pristine Sphagnum peatland) for shell construction, which is the cause of changes in the composition of TA and preference of species using those particles.

Small species of Difflugia genus (not determined in standard light microscopy) were also recorded. They are covered by both types of anthropogenic aluminosilicates as well as rock-derived minerals (Fig. 3). However, further investigation is needed to assess if selection of minerals is species-linked.

\section{Conclusions}

C. aerophila and P. acropodia-indicators of supply in mineral matter and atmospheric pollution in ombrotrophic peatlands, were distinguished. Centropyxis, Difflugia, and Phryganella possess different physiological mechanisms for shell construction using allochtonic particles. $\mathrm{Al}$ and $\mathrm{Cu}$ seem to be the most toxic elements and change the TA composition. Analysis of the concentration of toxic elements with mineralogical analysis and ecological traits of TA helps to better understand the response of microbial communities to environmental pollution. Finally, we strengthen the importance of the testate amoebae as the bioindicators of the recent atmospheric pollution.

Acknowledgments We thank the anonymous reviewer for the helpful comments that allowed to improve the manuscript. The research was funded by grant 2011/01/D/ST10/02579 from the National Centre of Science (NCN). We acknowledge the support of the grant PSPB-013/2010 from Switzerland through the Swiss Contribution to the enlarged European Union as well as a Research Program for the research group in JINR and in Poland.

Open Access This article is distributed under the terms of the Creative Commons Attribution License which permits any use, distribution, and reproduction in any medium, provided the original author(s) and the source are credited.

\section{References}

Booth, R. K., Lamentowicz, M., \& Charman, D. J. (2010). Preparation and analysis of testate amoebae in peatland paleoenvironmental studies. Mires and Peat, 7(2010/11), 17.

De Vleeschouwer, F., Fagel, N., Cheburkin, A., Pazdur, A., Sikorski, J., Mattielli, N., Renson, V., Fialkiewicz, B., Piotrowska, N., \& Le Roux, G. (2009). Anthropogenic impacts in North Poland over the last 1300 years - a record of $\mathrm{Pb}, \mathrm{Zn}, \mathrm{Cu}, \mathrm{Ni}$ and $\mathrm{S}$ in an ombrotrophic peat bog. Science of the Total Environment, 407, 5674-5684.

Deflandre, G. (1929). Le genre Centropyxis stein. Archiv Fur Protistenkunde, 67, 322-375.

Frontasyeva, M. V., \& Steinnes, E. (2005). Distribution of 35 elements in peat cores from ombrotrophic bogs studied by epithermal neutron activation analysis. Journal of Radioanalytical and Nuclear Chemistry, 265, 11-15.

Gomaa, F., Kosakyan, A., Heger, T. J., Corsaro, D., Mitchell, E. A. D., \& Lara, E. (2014). One Alga to rule them all: unrelated mixotrophic testate amoebae (Amoebozoa, Rhizaria and Stramenopiles) share the same symbiont (Trebouxiophyceae). Protist.

Grospietsch, T. (1958). Wechseltierchen (Rhizopoden). Stuttgart: Kosmos Verlag.

Holynska, B., Ostachowicz, B., Ostachowicz, J., Samek, L., Wachniew, P., Obidowicz, A., Wobrauschek, P., Streli, C., \& Halmetschlager, G. (1998). Characterisation of $\mathrm{Pb}-210$ dated peat core by various X-ray fluorescence techniques. Science of the Total Environment, 218, 239-248.

Jassey, V. E. J., Chiapusio, G., Mitchell, E. A. D., Binet, P., Toussaint, M. L., \& Gilbert, D. (2011). Fine-scale horizontal and vertical micro-distribution patterns of testate amoebae along a narrow fen/bog gradient. Microbial Ecology 61, 374-385.

Jassey, V. E., Chiapusio, G., Binet, P., Buttler, A., LaggounDefarge, F., Delarue, F., Bernard, N., Mitchell, E. A., Toussaint, M. L., Francez, A. J., \& Gilbert, D. (2013a). Above- and belowground linkages in Sphagnum peatland: Climate warming affects plant-microbial interactions. Global Change Biology, 19, 811-823.

Jassey, V. E. J., Meyer, C., Dupuy, C., Bernard, N., Mitchell, E. A. D., Toussaint, M.-L., Metian, M., Chatelain, A. P., \& Gilbert, D. (2013b). To what extent do food preferences explain the trophic position of heterotrophic and mixotrophic microbial 
consumers in a Sphagnum peatland? Microbial Ecology, 66, 571-580.

Jędrysek, M. O., Kałużny, A., \& Hoefs, J. (2002). S and O isotope ratios in spruce needles as a tracer of atmospheric pollution. Journal of Geophysical Research - Atmospheres, 107, 43534365.

Kabata-Pendias, A., \& Pendias, H. (1999). Biogeochemia pierwiastków śladowych, PWN.

Lamentowicz, M., \& Mitchell, E. A. D. (2005). The ecology of testate amoebae (Protists) in Sphagnum in north-western Poland in relation to peatland ecology. Microbial Ecology, 50, 48-63.

Lamentowicz, M., Tobolski, K., \& Mitchell, E. A. D. (2007). Palaeoecological evidence for anthropogenic acidification of a kettle-hole peatland in northern Poland. Holocene, 17, 1185-1196.

Lamentowicz, M., Forysiak, J., Balwierz, Z., Kloss, M., Kittel, P., Żurek, S., \& Pawlyta, J. (2009). Multiproxy study of anthropogenic and climatic changes in the last two millennia from a small mire in central Poland. Hydrobiologia, 631, 213-230.

Lamentowicz, M., Gałka, M., Milecka, K., Tobolski, K., Lamentowicz, Ł., Fiałkiewicz-Kozieł, B., \& Blaauw, M. (2013). A 1300 years multi-proxy, high-resolution record from a rich fen in northern Poland: reconstructing hydrology, land-use and climate change. Journal of Quaternary Science, 28, 582-594.

Lamentowicz, M., Gałka, M., Lamentowicz, Ł., Obremska, M., Kühl, N., Lücke, A., \& Jassey, V. E. J. (2015). Climate change over the last 4000 years in a Baltic bog in northern Poland revealed by a trait-based approach, biotic proxies, and stable isotopes. Palaeogeography Palaeoclimatology Palaeoecology, 418, 261-277.

Legendre, P., \& Gallagher, E. D. (2001). Ecologically meaningful transformations for ordination of species data. Oecologia, 129, 271-280.

Mazei, Y., \& Tsyganov, A. N. (2006). Freshwater testate amoebae. Moscow: KMK. 302 pp.

Ogden, C. G., \& Hedley, R. H. (1980). An Atlas offreshwater testate amoebae (pp. 1-222). London: Oxford University Press.

Oksanen, J., Blanchet, F. G., Kindt, R., Legendre, P., O'Hara, R. B., Simpson, G. L., Solymos, P., Stevens, M. H. H., \&
Wagner, H. (2011). Vegan: Community ecology package. R package version 1.17-7.

Payne, R. J., Mitchell, E. A. D., Nguyen-Viet, H., \& Gilbert, D. (2012). Can pollution bias peatland paleoclimate reconstruction? Quaternary Research, 78, 170-173.

Shotyk, W. (1996). Peat bog archives of atmospheric metal deposition: Geochemical assessment of peat profiles, natural variations in metal concentrations, and metal enrichment factors. Environmental Reviews 4(2):149-183.

Smieja-Król, B., \& Fiałkiewicz-Kozieł, B. (2014). Quantitative determination of minerals and anthropogenic particles in some Polish peat occurrences using a novel SEM pointcounting method. Environmental Monitoring and Assessment, 1-15.

Smieja-Król, B., Fiałkiewicz-Kozieł, B., Sikorski, J., \& Palowski, B. (2010). Heavy metal behaviour in peat - a mineralogical perspective. The Science of the Total Environment, 408, 5924-5931.

Swindles, G. T., Reczuga, M., Lamentowicz, M., Raby, C. L., Turner, T. E., Charman, D. J., Gallego-Sala, A., Valderrama, E., Williams, C., Draper, F., Honorio Coronado, E. N., Roucoux, K. H., Baker, T., \& Mullan, D. J. (2014). Ecology of testate amoebae in an amazonian peatland and development of a transfer function for palaeohydrological reconstruction. Microbial Ecology, 68, 284-298.

Szynkiewicz, A., Modelska, M., Jędrysek, M. O., \& Mastalerz, M. (2008). The effect of acid rain and altitude on concentration, $\mathrm{d} 34 \mathrm{~S}$, and $\mathrm{d} 18 \mathrm{O}$ of sulfate in the water from Sudety Mountains. Chemical Geology, 249, 36-51.

Team, R. D. C. (2013). R: A language and environment for statistical computing. R Foundation for Statistical Computing, Vienna, Austria. ISBN 3-900051-00-3, URL http://www.R-project.org.

Tsyganov, A. N., Aerts, R., Nijs, I., Cornelissen, J. H., \& Beyens, L. (2012). Sphagnum-dwelling testate amoebae in subarctic bogs are more sensitive to soil warming in the growing season than in winter: the results of eight-year field climate manipulations. Protist 163, 400-414.

Wilken, S., Huisman, J., Naus-Wiezer, S., \& Van Donk, E. (2013). Mixotrophic organisms become more heterotrophic with rising temperature. Ecology Letters 16, 225-233. 